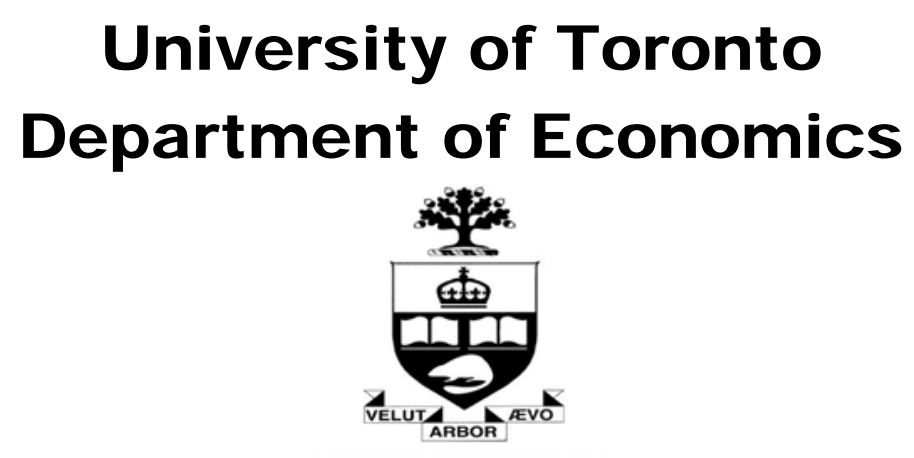

Working Paper 456

The Technology and Economics of Coinage Debasements in Medieval and Early Modern Europe: with special reference to the Low Countries and England

By John H. Munro

June 06, 2012 


\section{Department of Economics \\ University of Toronto \\ 150 St. George Street \\ Toronto, Ontario M5S 3G7 \\ Canada}

\section{The Technology and Economics of Coinage Debasements in Medieval and Early Modern Europe: with special reference to the Low Countries and England}

\section{Working Paper no. 456 (MUNRO: WP no. 43)}

Repec Handle: tecipa-456

by John Munro

Wednesday, 6 June 2012

Copyright (C) by John Munro 2009-2012

Department of Economics

University of Toronto

Author's e-mail: munro5@chass.utoronto.ca

http://www.economics.utoronto.ca/munro5

On-line version: http://www.economics.utoronto.ca/index.php/index/research/workingPaperDetails/456

Keywords: coinage debasements; 'Great Debasement'; gold; silver; billon; bullion; bullionist policies; mints; mint outputs; seigniorage; brassage; token coinages; 'small change’; Gresham’s Law; inflation; deflation; 'bullion famines' and monetary scarcities; warfare; taxation; France; Flanders; dukes of Burgundy; England; Henry VIII.

JEL Classifications: E 31; E41; E42; E51; E52; E62; F33; H11; H27; N13; N23; N43 


\title{
The Technology and Economics of Coinage Debasements in Medieval and Early Modern Europe: with special reference to the Low Countries and England
}

\begin{abstract}
:
Coinage debasement in medieval and early modern Europe remains an ill-understood topic; and indeed an often cited article ('The Debasement Puzzle': Velde and Weber, 1996) sought to demonstrate that coinage debasements were both impractical and economically futile. The purpose of this study is to demonstrate that aggressive debasements were generally very practical and effective, so long as they were properly devised to profit both the merchants who brought bullion to the mints and the princes who earned seigniorage revenues from those mints. To be sure, the general public often suffered the consequences of this 'seigniorage tax' from the consequent inflation. But another goal of this study is to demonstrate that inflation was almost never proportionate to the extent of the debasement, even during Henry VIII's 'Great Debasement' (1542-53); and to demonstrate that both merchants and the prince benefitted from debasements in 'real' terms, provided that they spent the increased quantity of now debased coins (of the same face value) quickly enough, before the full force of inflation was felt.

Central to the economic success of such debasements was the pre-modern mint technology: the very crudity of the techniques of 'hammered' coinages whose mint outputs did not produce fully identical coins in each issue. For this and many other reasons explored in this study, domestic merchants and the general public almost always accepted coins by 'tale' (number), at face value, and did not discount them for deficiencies in weight and fineness - except for those merchants dealing with gold coins in international trade.

The second part of this study is an examination of the European princes' motives for conducting such coinage debasements. As the previous argument and so many previous studies have indicated, an obvious motive was profit-seeking - so that such debasements may be regarded more as fiscal than truly monetary policies. But an equally powerful and perhaps even more widespread monetary motive was defence of the realm's coinages and mints: i.e., necessary defences and retaliations against aggressive, profit-seeking debasements undertaken by neighboring prices (or city states). In essence, that meant a defence against the operations of Gresham's Law, whose frequency and effectiveness in international monetary flows are also examined in this study. The operation of Gresham's Law also involved, however, the deterioration of the general standard of domestic coins through counterfeiting, fraudulent 'clipping and sweating' of the coins, and especially by normal wear and tear in domestic circulation. Such deterioration, for all these reasons, thus meant that freshly minted, full-bodied 'good coins' were soon driven out of circulation (exported abroad, melted down, or just hoarded) by the prevailing circulation of 'bad' coins - thus necessitating a defensive debasement to reduce the mint standard, in weight and fineness, to that of the prevailing circulation. The problem of Gresham's Law, related to both aggressive and defensive debasements, was resolved - to obviate debasements - only by the advent of modern steam-powered machinery to produce perfectly round, milled, and exact replicas of coins struck.

The final but brief aspect of this study is to answer the question raised by Sargent and Velde in their recent monograph: The Big Problem of Small Change (2002). Were such coinage debasement ever undertaken as a deliberate policy to expand the money supply (especially during the late-medieval 'bullion famines') and in particular to remedy any chronic shortage of petty coins or 'small change': other than as a defensive reaction to Gresham's Law? The answer advanced in this study, briefly, is simply NO (for the reasons explored in the conclusion).
\end{abstract}

Keywords: coinage debasements; 'Great Debasement'; gold; silver; billon; bullion; bullionist policies; mints; mint outputs; seigniorage; brassage; token coinages; 'small change’; Gresham’s Law; inflation; deflation; 'bullion famines'; warfare; taxation; France; Flanders; dukes of Burgundy; England; Henry VIII.

JEL Classifications: E31; E41; E42; E51; E52; E62; F33; H11; H27; N13; N23; N43; N93. 


\title{
The Technology and Economics of Coinage Debasements in Medieval and Early Modern Europe: with special reference to the Low Countries and England
}

\section{John H. Munro, University of Toronto}

\begin{abstract}
$* * * * * * * * * * * * * * * * * * * * * * * * *$
Coinage debasements in pre-Industrial Europe, despite their frequency and especially their severity during the late-medieval guerres monétaires, and despite their often important economic consequences, remain a subject that is often mentioned but remains ill understood in the economic history literature. Indeed, one often-cited article, aptly titled ‘The Debasement Puzzle’ (1996), by three highly respected economists, sought to demonstrate that coinage debasements were both impractical and economically futile. ${ }^{1}$ Yet debasements continued to 'plague' Europe until the eighteenth century. The objective of this study is to demonstrate that they were both practical and often quite effective in their often very different goals, and were not always so deleterious in their effects as is traditionally portrayed.
\end{abstract}

\section{Medieval coinages and their relation to moneys-of-account}

The nature, techniques, and economic consequences of European coinage debasements must be understood first in relation to the local money-of-account system for that coinage. In medieval and earlymodern western Europe (except or for the Iberian peninsula and parts of Germany), most local moneys-ofaccount were based upon the system that was established under Charlemagne, ca. 795. It was directly linked to the new Carolingian pound weight of fine silver $(489.51 \mathrm{~g})$ in that the pound money-of-account was given the precise value of this weight of fine silver. ${ }^{2}$ Obviously no silver coins weighing a pound were struck; and for centuries, the only silver coins struck were the various regional pennies (and their subdivisions). Solely for accounting purposes, in reckoning prices, wages, values, etc., the pound money of account (libra, livre, lira) was subdivided into 20 shillings (based on the Roman gold solidus), which in turn were subdivided into 12 pence (based on the Roman silver denarius), so that this pound of account always consisted of 240 currently circulating silver pennies. ${ }^{3}$ Not until the thirteenth century did some Italian city states and then

1 Arthur Rolnick, François Velde, and Warren Weber, 'The Debasement Puzzle: An Essay on Medieval Monetary History’, Journal of Economic History, 56:4 (December 1996), pp. 789-808. See also François Velde, Warren Weber, and Randall Wright, 'A Model of Commodity Money, with Applications to Gresham’s Law and the Debasement Puzzle’, Review of Economic Dynamics, 2:1 (1999), pp. 291-333.

${ }^{2}$ See Etienne Fournial, Histoire monétaire de l'Occident médiéval (Paris: F. Nathan, 1970), pp. 23-7.

3 When England, after the Norman Conquest (1066), established its own monetary system, the Tower Pound of fine silver (12 oz) was similarly struck into 240 pennies and subdivisions (half pence and farthings). Nicholas J. Mayhew, 'From Regional to Central Minting, 1158-1464', in Christopher Challis (ed.), 
France introduce heavier weight silver coins, known as grossi or gros. ${ }^{4}$ The primary reason for issuing such larger, 'full bodied' coins was the deterioration in the silver contents of the original penny through the ensuing centuries of almost universal, if periodic coin debasements, and the consequent rise in prices in each region's silver-based money-of-account. At the accession of King Philip II Augustus in 1180, the French silver denier parisis contained only $0.509 \mathrm{~g}$ of commercially fine silver (argent-le-roy): only about half as much as the $1.020 \mathrm{~g}$. of fine silver contained in the original Carolingian denier of ca. $795 .^{5}$

\section{The forms and nature of medieval coinage debasements}

Medieval coinage debasements normally took two different forms. The first, and by far the most common, was a physical decrease in the quantity of silver or gold contained in current coins of the same face value; and that meant, therefore, a corresponding reduction in the quantity of such precious metals represented in the related money-of-account: the penny, the shilling, and the pound. The mint undertook such physical debasements by two different means, but often in combination: by reducing the weight of the coin itself; and/or, by diminishing the coin's precious-metal fineness. The latter method simply meant adding more and more base metal, copper, to the alloy. As a consequence of either or both physical methods a pound or marc weight of fine metal was struck into a greater number of coins, of each denomination, with a consequent increased money-of-account value of that pound or marc of fine metal so struck into the newly debased coins. At the same time, the face value of the currently circulating penny, whatever its fine silver content, always retained the value of $1 \mathrm{~d}$. in the local money of account.

The alternative but mathematically related form of debasement was, paradoxically, the seeming opposite: an increase in the money-of-account value of the coin concerned, a method chiefly applied only to the gold coinages. Almost invariably, a physical debasement of the silver coinages necessarily required

A New History of the Royal Mint (Cambridge: Cambridge University Press, 1992). pp. 1-82, 83-178. In the first extant mint accounts, for Henry III in 1247, 242 pence were struck from the Tower Pound of sterling silver, $92.50 \%$ pure (11 oz 2 dwt silver and 18 dwt copper).

${ }^{4}$ See Peter Spufford, Money and Its Use in Medieval Europe (Cambridge: Cambridge University Press, 1988), pp. 226-7; Frederic C. Lane and Reinhold Mueller, Money and Banking in Medieval and Renaissance Venice, vol. 1: Coins and Moneys of Account (Baltimore and London: The Johns Hopkins University Press, 1985), pp. 10-11, 114-15 (noting that the decision to issue grossi coins may date from 1194); Fournial, Histoire monétaire, pp. 78-9.

${ }^{5}$ Adrien Blanchet and Alphonse Dieudonné(eds.), Manuel de numismatique française, 2 vols. (Paris: Ricard, 1916), vol. II, pp. 218-22. 
a compensatory debasement of the gold coinage, if only by raising that coin's money of account value, in order to maintain an equilibrium or balance between the market values of the two precious metals and the corresponding mint ratio. In this era, the normal bimetallic ratio - the ratio of the market values of gold to silver - varied between 11:1 to 12:1. If, for example, the prince debased just the silver coinage, thereby raising the relative money-of-account value of a marc or pound of silver, he would automatically have altered the mint's bimetallic ratio to 'favour' silver, and thus to 'disfavour' gold. He may have done so deliberately in order to attract an increased supply of silver into his mints. But the 'opportunity cost' of doing so was some corresponding loss of gold coins or bullion, which merchants would export to seek higher exchange values abroad, either on the market or at foreign mints. If the corresponding changes in these mint ratios exceeded the value of the mint charges (equivalent to the 'gold shipping' points under the modern gold standard), the prince would have suffered an unwanted loss of gold. Therefore, to protect his mints from such unwanted losses of gold, the prince would have debased his gold coinages as well, to some corresponding degree. While, as just indicated, many princes chose to do so simply by raising the money-of-account or exchange value for their gold coins, some did so either by physically debasing the existing gold coins, or by issuing entirely new coins with a lesser amount of gold, and with correspondingly exchange rates, calibrated to match the market ratios. Note that in most of medieval and early-modern Europe, the values of gold coins were always expressed in terms of the silver-based money-of-account.

When this technique was applied to silver coins, only the higher-denomination coins were subjected to such an increase in their money-of-account or exchange values, while the penny and other lowerdenomination coins underwent physical debasements. The most famous example took place during the first debasements of France's Philip IV the Fair (r 1285-1314), the monarch responsible for launching the disastrous late-medieval guerres monétaires. Initially, from 1295 to 1303, he debased only the silver denier coins, while maintaining the fineness and weight of the prized gros tournois, the sou or shilling coin that Louis IX had introduced in August 1266. But he was forced to raise its money-of-account value from 12d to $15 \mathrm{~d}$ tournois, and then (after 1303) to 26.25 d.t., while also reducing its fineness by 25 percent. $^{6}$

\footnotetext{
${ }^{6}$ Blanchet and Dieudonné, Manuel de numismatique, pp. 225-42. St. Louis’s gros tournois was struck at a full 12 deniers argent-le-roy, with 58 struck to the marc de Troyes; in 1303, he reduced the fineness to 9 deniers; with a partial monetary reform in 1306, he restored its former fineness, but with a face value of 13.125d tournois. In Flanders, the market value rose much further during these years (to 36d parisis = 28.8d tournois). Under Philip V (1316-22), the gros tournois retained its full fineness (12 deniers), but
} 
Whatever the method employed, the consequence of any debasement, of both silver and gold, was a reduction in the precious-metal content of the money-of-account units: the penny, shilling, and pound.

\section{The legal and commercial advantages in using legal-tender coin instead of bullion}

Finally, the economic and legal distinctions between coined money and bullion are necessary to understand fully the nature and economic of medieval, early-modern debasements. In most European realms during this long era (except for the Italian city-states and early-modern Holland), especially from the commencement of the guerres monétaires, in the late thirteenth, early fourteenth century, trading in or exporting 'bullion' was illegal, with severe penalties in the form of both confiscation of the metals and fines (or even prison or exile). In most such realms, the legal definition of ‘bullion' excluded all legal-tender coins and those metals allotted, by licence only, to goldsmiths and jewellers to be fashioned into plate, jewellery, or other industrial goods. Some bullion exports were permissible: for government agents on official business abroad and for some merchants engaged in international trade, but only on the purchase of costly licences. Otherwise, all other forms of precious metals not covered by these exemptions had to be surrendered to the ruler’s mints for conversion into domestic legal tender coins.

Similarly, these principalities also prohibited the importation and circulation of foreign silver coins and most foreign gold coins, with the exception of some favoured international 'dollars' of the day: e.g., Florentine florins, Venetian ducats, English nobles, French écus. Apart from those exceptions, they were also declared to be 'bullion', with the obvious requirement that they too be delivered to the ruler's mints for recoinage. ${ }^{7}$ England's Parliament went even further, with legislation in force from January 1364 to May 1663 that prohibited the export of all forms of precious metal (except under licence) - all gold, all silver, in both bullion and legal tender coin - and also the domestic circulation of any foreign coins (except briefly, in the 1520s, under Henry VIII). ${ }^{8}$ The aim of such bullionist proto-Mercantilist legislation was to protect the

with a reduced weight (59.167 to the marc) and an increased face value of $15 \mathrm{~d}$. tournois.

${ }^{7}$ The medieval terms for bullion were: billon, billoen, billio - as defined above in the text. See John Munro, 'Billon - Billoen - Billio: From Bullion to Base Coinage', Revue belge de philologie et d'histoire/ Belgisch tijdschrift voor filologie en geschiedenis, 52 (1974), pp. 293-305, which explains how the meaning of billon changed, over the centuries, so that the modern term 'billon' means a base or petty coin, one in which silver constitutes less than half of the metallic content.

8 See John Munro, 'Bullionism and the Bill of Exchange in England, 1272-1663: A Study in Monetary Management and Popular Prejudice', in Center for Medieval and Renaissance Studies, UCLA (ed.), The Dawn of Modern Banking (New Haven and London: Yale University Press, 1979), Appendix A-B, pp. 
domestic realm from debased or otherwise fraudulent foreign and to promote an increase in the ruler's own mint outputs.

For most merchants and the general public, using coin rather than bullion provided two major savings in transaction costs. First and most obvious was in avoiding the risks and thus costs of confiscation and heavy fines, but also the costs of obtaining licences for legal exports of bullion. The second and far less obvious advantage lay in avoiding the costs of estimating the true market value of the precious metals: that is, the very error-prone costs of weighing the precious metals and assaying their true fineness, and of then ascertaining the proper money-of-account values. In contrast, legal-tender coins, stamped with identifying symbols on the obverse and reverse, as the sovereign's guarantee of their true precious-metal value, allowed them to circulate by 'tale' - i.e., by counting the coins, at their assigned 'face value'. The lower the denomination, the higher was the transaction cost of assaying coins and not accepting them by tale.

One of the most contentious issues in monetary history is whether or not coins 'passed' or circulated by tale; and the denial that they did so constitutes a prime reason for doubting the efficacy of medieval debasements. All of the available commercial evidence does indicate that silver coins were accepted at official face value in domestic trade, with only rare exceptions. Consider the fact that by the later Middle Ages almost all European silver pennies had undergone some debasements, yet all were still treated as pennies in commerce. For example, the first Flemish silver penny groot, struck in May 1300, had an almost perfect fineness (95.667 percent), containing 3.794 g pure silver; but, by the coinage ordinance of June 1418, that same Flemish silver penny groot had a fineness of only 41.667 percent and contained only 0.850 g pure silver: just 22.40 percent as much as in the original penny. Are we to assume that the 1418 single groot then circulated at a discounted value of just slightly more than one-fifth of a penny? ${ }^{9}$ Thus, when did such discounting of silver pennies commence; and how was it calculated, in usable commercial values, over time? These questions reveal the very absurdity of denying the obvious: that penny coins always circulated by tale

216-25, citing in particular statutes 38 Ed III, stat. 2, c. 14 (1364) and 15 Car.II, c. 7 (1663); and John Munro, 'The Coinages and Monetary Policies of Henry VIII (r. 1509-47)', in Charles Fantazzi (translator) and James Estes (ed.), The Collected Works of Erasmus: The Correspondence of Erasmus, Vol. 14: Letters 1926 to 2081, A.D. 1528 (Toronto: University of Toronto Press, 2011), pp. 423-76.

${ }^{9}$ See accounts in Victor Gaillard (ed.), Recherches sur les monnaies des comtes de Flandre, 2 vols, (Ghent: H. Hoste, 1856); John Munro, Wool, Cloth, and Gold: The Struggle for Bullion in Anglo-Burgundian Trade, 1340 - 1478 (Brussels and Toronto: Éditions de l’Université de Bruxelles, 1973). 
at this face value, irrespective of their intrinsic metal contents. ${ }^{10}$ We might assume, however, that gold coins were more likely to circulate at 'market' values than by tale; but the evidence for England and the Low Countries indicates that, except for times of radical debasements, or sudden shifts in the market's bimetallic ratios, most gold coins did circulate at official values: but only so long as the public retained confidence in the ruler's coins, as stamped with his insignia. ${ }^{11}$

That considerable savings in these two sets of transaction costs correspondingly provided legal tender coins, including legal-tender foreign coins, with an agio or premium over their bullion values. ${ }^{12}$ That premium value represented the sum of the mintage fees, which were deducted from the total value of the coins produced from the bullion: a value known as the traite in medieval Flanders, and the pied de la monnaie in France. ${ }^{13}$ So long as this agio was at least equal to the sum of the mintage fees, so that coins remained more valuable than bullion, merchants would continue to deliver bullion to the mints. Conversely, whenever domestic coins lost that agio, bullion would cease to be delivered to the prince's mint, and would most likely be either hoarded or exported to some foreign mint, where it commanded a higher exchange value.

\section{The Mint Price and the Mintage Fees: Brassage and Seigniorage fees}

The mint price for bullion was the total coined value (known as the traite) less the sum of the minting fees, which consisted of two distinct elements: brassage, for the mint-master, and seigniorage, for

${ }^{10}$ See Rolnick, Velde and Weber, 'The Debasement Puzzle', pp. 789-808, in n. 1 above. More recently, the view that medieval coins did circulate by tale has been reluctantly accepted (by Velde) in Thomas Sargent and François Velde, The Big Problem of Small Change (Princeton and Oxford: Princeton University Press, 2002), pp. 16-19, 22, 75 - 322: 'that the market often valued coins partly by tale'.

${ }^{11}$ See the evidence cited in Munro, Wool, Cloth, and Gold; and in studies in John Munro, Bullion Flows and Monetary Policies in England and the Low Countries, 1350 - 1500, Variorum Collected Studies series CS 355 (Aldershot, Hampshire; and Brookfield, Vermont: Ashgate Publishing Ltd., 1992).

${ }^{12}$ An examination of the official values or exchange rates for foreign gold coins circulating in the Low Countries (e.g., ducats, florins, English nobles, French écus), and in England in the 1520s, reveals that they also such a premium: a agio lower than that on domestic Flemish gold coins but an amount still higher than the mint price for gold bullion. See exchange rates listed in John Munro, 'Money, Wages, and Real Incomes in the Age of Erasmus: The Purchasing Power of Coins and of Building Craftsmen's Wages in England and the Southern Low Countries, 1500 - 1540', in Alex Dalzell and Charles G. Nauert, Jr. (eds.), The Collected Works of Erasmus: The Correspondence of Erasmus, Vol. 12: Letters 1658 - 1801, January 1526-March 1527 (Toronto: University of Toronto Press, 2003), Appendix: pp. 551-699; and Munro, 'Coinages and Monetary Policies of Henry VIII', pp. 423-76.

${ }^{13}$ The mathematical formula for computing the traite is: $\mathrm{T}=\mathrm{t} . \mathrm{V} / \mathrm{F}$; or traite $=$ taille per marc (number of coins cut from the marc) times the face value of the coin, divided by the percentage fineness (alloy) of the coin. For the pied de la monnaie, which is the traite multiplied by 5, see Fournial, Histoire monétaire, pp. 30-1. 
the prince (or republican government). Both fees were specified in nominal money account, in terms of the currently debased (or reformed coinage), though really as a percentage of the bullion brought to be coined. Brassage was an economically necessary fee for the simple reason that it literally 'costs money to make money'. That fee thus compensated the mint-master for his own production costs: above all, the cost of the copper alloy; the capital costs of maintaining the mint, in the form of his dye tools (hammers), the furnaces, forges, melting pots, shears; the administrative costs of managing the mint - including light, heat, and rent; the labour costs of producing the actual coins and running the mint; and finally the cost of licence fees paid to the prince and other fees paid to official coin assayers and mint inspectors. Such costs were normally relatively modest, except for the low-valued petty coinage, whose production entailed a relatively higher cost in copper alloys and in labour (i.e., more coins cut per alloyed marc or pound). The capital cost of building the mint itself was usually born by the prince or town government.

The other fee was the prince's seigniorage, arguably a less necessary fee from the vantage point of the economy, but not from the point of view of the prince. Most princes indeed claimed the right to exact a profit from the coinage, one based on their royal or princely prerogative in maintaining a monopoly on their realm's coinages. Depending on the circumstances that led to any debasement, the seigniorage fees might have been relatively modest or relatively high. In the latter case, whether the prince was driven to debase the coinage out of avarice or dire economic necessity, he was still restrained in setting his seigniorage fees by having to offer a mint price that was competitive with those from neighbouring mints. For obviously, the higher the seigniorage fee, the lower would be the mint price - and too low a price would thus discourage or even prevent an influx of bullion to his mints.

The objective of most debasements, therefore, was to set a new, higher mint price for one or both metals that would satisfy two objectives, which were not always compatible: first, to attract more bullion, foreign and domestic, to the prince's mint by offering a real gain to merchants; and second, to allow the prince to augment (or at least maintain) his mint seigniorage revenues. The domestic sources of bullion included both domestic precious-metal hoards, often in the form of household plate and jewellery, but especially the previous issues of the prince's coins, which were usually demonetized at the time of the debasement. Thus the new mint price had to be high enough to compensate merchants and the public for the total mintage fees that had been paid on the former coin issues. Obviously, the new mint price also had to 
be high enough to attract bullion away from foreign, competing mints, while also discouraging the export of precious metals. As indicated earlier, one danger inherent in all debasements was that 'favouring' one metal (by a more extensive debasement) might undervalue the other metal and thus promote its export abroad to mints and regions with a more favourable bimetallic ratio for that other metal.

\section{Motives for late-medieval coinage debasements, I: aggressive fiscal motives (profit-seeking)}

Most monetary historians have focused on the aggressive debasements: as profit-seeking, fiscally motivated enterprises, chiefly to finance both warfare and defence. Indeed, the French philosopher and monetary observer, Nicholas Oresme bluntly and succinctly stated as much, in his famous treatise De Moneta, ca. $1355::^{14}$

I am of the opinion that the main and final cause why the prince pretends to the power of altering the coinage is the profit or gain that he can get from it; [for] it would otherwise be vain to make so many and so great changes.

How a prince's mint profits could be so increased can be seen Table 1, for the debasement of the Flemish silver double groot coin (worth 2d) that Duke Philip the Good of Burgundy undertook in November 1428.

In comparison with the previous silver double groot issued in 1418, this debasement reduced the coin's fine silver content by 0.203 grams, or 11.77 percent. The fineness itself was diminished from 47.92 percent purity to 42.59 percent; and the weight fell from 1.800 grams (68 to the $\operatorname{marc}$ ) to 1.588 grams (68.5 to the $\operatorname{marc}$ ). As a consequence the number of double groot coins struck from a fine marc of silver increased from 136 to 154.125 such coins, thus increasing the traite or coined value of the marc from 22s 8d (136 * 2d) to 25s 8d 6 mites (8.25d) groot Flemish. ${ }^{15}$

By this debasement, the total mintage fees rose from 1s $6 \mathrm{~d}$ to $1 \mathrm{~s} 8 \mathrm{~d} 6$ mites per fine marc of silver. Of the two fees, the seigniorage was increased, in nominal terms, by fifty percent: from $4 \mathrm{~d}$ to $6 \mathrm{~d}$ (in real terms, from 1.47 percent to 1.95 percent of the fine marc coined). The mint-master's brassage, on the other

14 Original text from De origine, natura, jure et mutationibus monetarum, published in Charles Johnson (ed.), The 'De Moneta' of Nicholas Oresme and English Mint Documents (London: Thomas Nelson and Sons, 1956), chapter XV, p. 24. On Oresme's monetary philosophies, see Spufford, Money and Its Use, pp. 295-304; and Émile Bridrey, La Théorie de la monnaie au XIVe siècle: Nicole Oresme: étude d'histoire des doctrines et des faits économiques (Paris: Girard et Brière, 1906).

${ }^{15}$ The mite or mijt was a petty Flemish coin, largely copper, of which 24 mites $=1 \mathrm{~d}$. groot. See also n. 46 below. 
hand, was increased from only 1s 2d to 1s 2d 6 (2.25d) mites, and in real terms it fell: from 5.15 percent to 4.62 percent of the fine marc so coined. Obviously this debasement was instigated by the duke's own fiscal needs (during his wars in Holland and France), and can hardly be blamed on profit-seeking from the mintmaster, whose minuscule increase of 6 mites per fine marc could hardly have compensated him for the increased costs in copper alloy and labour.

Indeed, the total mintage fees, as a percentage of bullion coined, fell from 6.62 percent to 6.57 percent of the bullion coined; and that decline necessarily meant an increase, in both nominal and real terms, in the merchants' price for bullion (the mint-price). That mint rose, per marc of fine silver, from 22s $8 \mathrm{~d}$ to 24s 0d groot Flemish: and thus from 93.38 percent to 93.43 percent of the bullion coined.

No medieval prince or ruler could have succeeded in undertaking an aggressive, profit-oriented debasement without having secured the co-operation of both domestic and foreign merchants, i.e., to entice them to bring more bullion to the mint by offering them an increased real gain in doing so. As Table 1 indicates, the 1428 debasement offered merchants a significantly higher mint price for silver bullion, in terms of a marc of fine silver, argent-le-roy: 144 double groot coins, an amount 13.4 percent higher than the previous mint price of 127 double groot coins.

Obviously, merchants converting their bullion into the newly debased coin could gain only if the public accepted them by tale. The previous explanations on the substantial savings in transaction costs in doing so - as opposed to treating such coins as bullion -- may seem less convincing in these times of debasement. The ancillary argument to explain why the public would continue accepting debased coins by face value lies in the crudity of medieval minting technology.

\section{The technology of pre-modern hammered coinages and coinage circulation by tale}

The outputs of mints using that technology is known as hammered coinage. The first step in minting was to produce coin blanks: silver disks cut from thin sheets of silver, alloyed to the proper degree with copper. Each blank was placed on a lower dye, serving as the anvil, to allow the mint-master to use the other dye as a hammer, to strike the blank. Each dye, obverse (top) and reverse (bottom), was configured with the emblems or stamps that had the ruler had designed for his coins. Once struck, the now flattened, elongated coin had to be trimmed with shears to approximate the desired circular shape of the coin.

As a consequence of all these procedures, no coins struck in one session of minting had exactly the 
same size, shape, and weight of the other coins in that lot. Indeed, mint regulations did not stipulate specific weights for each coin but specified rather a taille: the number of such coins to be cut from the pound or marc. These regulations necessarily permitted some reasonable variance - a tolerance known as the remède - per marc of fine silver. Thus, very few if any persons handling individual coins issued from a debasement by weight would have been able to tell the difference between current coins and past coins, and good coins from bad, provided that the changes were modest. Even if those who possessed accurate scales - a heavy cost for most tradesmen and retail merchants - would have had to weigh a very large number of such coins of the same denomination to be confident of detecting any debasement or any other fraudulent tampering.

Changes in the coin's fineness - especially when as minor as that indicated for the Flemish debasement of 1428 (a change of 4.16 percent) - would have been even more difficult to detect, even with a touchstone, which most tradesmen also did not possess. According to some numismatic historians, medieval touchstones were at best accurate only for changes in fineness of from five to ten percent. ${ }^{16}$ Even visual inspections that detected changes in the prince's stamps on the obverse and reverse sides of the coins would not have been conclusive since such changes often took place with changes in mint officials, without any debasements. Thus moderately debased coins - especially those from such a combination of hard-to-detect reductions in weight and fineness — would have continued to circulate locally by tale.

\section{The relationship between debasement and inflation}

The second and even more important requirement for a successful debasement was that any consequent inflation - threatening to reduce or even eliminate the merchants' real gain - should have taken place only after the merchants had sufficient time to spend their newly acquired coins. Surely only those subscribing to a very crude quantity theory of money would believe that inflation was an immediate consequence of debasement. The historical record of prices almost always indicates some considerable time lag: the time required for the extra quantity of coins to enter full circulation and for the general public to

16 Philip Grierson, Numismatics (Oxford: Oxford University Press, 1975), pp. 100-11, 150-55; Philip Grierson, 'Medieval Numismatics,' in James Powell ( ed.), Medieval Studies: An Introduction (Syracuse, Syracuse University Press, 1976), pp. 124-34; Philip Grierson, 'Coin Wear and the Frequency Table,' Numismatic Chronicle, $7^{\text {th }}$ ser. 3 (1963): pp. i-xv; Philip Grierson, 'Weight and Coinage,' Numismatic Chronicle, $7^{\text {th }}$ ser. 4 (1964), pp. iii-xvii; Albert Girard, 'La guerre des monnaies,' Revue de synthèse 19 (1940-45), pp. 83-101; Fournial, Histoire monétaire, pp. 9-38. 
become more fully aware of the consequences. ${ }^{17}$ Medieval merchants converting bullion into coin generally enjoyed the benefits of asymmetric information: that they were privy to knowledge about the particulars of the debasement that remained unknown for some time to the general public. ${ }^{18}$

The more important consideration, however, is that coinage debasements rarely, if ever, produced inflations in proportion to the percentage reduction in the particular coin's precious metal contents, even several years after the coinage changes. The obverse nature of that relationship must first, however, be clearly understood; for it is fallacy to believe that, for example, a ten-percent debasement should have led to a tenpercent inflation, even in accordance with the crude quantity theory of money. The relationship is instead one of reciprocals: an increase in prices as a consequence of a decrease in fine metal content, as indicated by the following formula:

\section{$\Delta T($ traite $)=[1 /(1-x)]-1$}

In this formula, $\Delta \mathbf{T}$ represents the percentage change in the money-of-account value of the traite - here, the coined value of the marc weight of fine silver (argent-le-roy); and the symbol $\boldsymbol{x}$ represents the percentage reduction in the precious metal of the coin (silver). Thus, by this formula, a 10-per cent reduction in the fine silver contents of the penny (groot) would automatically have increased the nominal coined value of the marc of silver (argent-le-roy), not by 10 percent but by 11.11 per cent. It is the latter percentage increase (or the percentage increase in the mint price) that must be compared to the increase in the Consumer Price Index. ${ }^{19}$ Whether any increase in the money supply (probably less than indicated by the extent of the debasement) led to any comparable inflation is not supported by the historical record. For Flanders during the entire Burgundian era (1384-1482), for example, the fine silver content of the Flemish penny groot diminished from 1.173 grams in September 1384 to 0.466 grams in July 1482, a loss of 0.707 grams

\footnotetext{
${ }^{17}$ See John Munro, ‘Money, Prices, Wages, and “Profit Inflation” in Spain, the Southern Netherlands, and England during the Price Revolution era, ca. 1520 - ca. 1650', História e Economia: Revista Interdisciplinar, 4:1 (2008), pp. 13-71.

${ }^{18}$ See Neil Gandal and Nathan Sussman, 'Asymmetric Information and Commodity Money: Tickling the Tolerance in Medieval France’, Journal of Money Credit and Banking, 29:4 (November 1997), pp. 440457.

${ }^{19}$ See Peter Spufford, 'Debasement of the Coinage, its Effects on Exchange Rates and the Economy in England in the 1540s, and in the Burgundian-Habsburg Netherlands in the 1480s', in John Munro, ed., Money in the Pre-Industrial World: Bullion, Debasements and Coin Substitutes (London: Pickering \& Chatto Ltd., 2012), pp. 63-85.
} 
$=60.27$ per cent of its 1384 contents. The corresponding value of traite per marc argent-le-roy rose from 16.667 s. groot (=£3.553 per kilogram of pure silver) in 1384 to 41.920 s groot (=£8.936 per kg of pure silver) in 1482: an increase of 151.51 percent. Over the 98-year period from 1386 to 1484 (allowing a two-year time-lag), the Flemish Consumer Price Index (base: 1451-75 = 100) rose from 139.658 to 224.457: an increase of only 60.72 percent. $^{20}$

A better if far more complex test would be to calculate the recorded price changes after specific debasements, in Burgundian Flanders, for subsequent two year periods. The calculations for such changes, with these relationships between debasements and the price level, can be found in Table 2: for Flanders and England. For the sake of proper comparisons, the aforesaid money-of-account value of the two traites (Flemish and English) is expressed here in a measure common to both countries: the coined money-ofaccount values of a kilogram pure silver. The object of the investigation is to compare the increases in these traite values with the ensuing changes in the Consumer Price Index, for the two years following each debasement.

In Part A, for the Flemish coinage debasements in the fifteenth century, up to the end of the Burgundian era (1482), we find, with two exceptions, that the percentage increase in the CPI was less than the percentage increase in the coined value of the silver traite. The first exception, for the 1416 debasement (the first in the fifteenth century), is a most curious one. It was followed by a fall, not a rise, in the price level: a decline of 22.43 percent, from 1416 to 1418 . In the second exception, for the debasement of 1477, the very sharp rise in the CPI over the next two years (1477 to 1479) was followed by a 22.5 percent fall in the CPI (from 149.327 to 115.679. The subsequent Flemish coinage debasements, during the rule of the Habsburg Archduke Maximilian of Austria, from 1484 to 1496, are too complex to summarize in this table. ${ }^{21}$ The accompanying bouts of inflation were also the product of warfare - wars with France and civil wars, with Flemish revolts against the Habsburg rulers. But, in summary, the rise in the mint's traite value of coined silver (as the direct reflection of those debasement) rose from £6.821 groot per kilogram of pure silver in 1484 to a final $£ 15.804$ per kg in 1489 (briefly at $£ 17.480$ in 1488): an overall rise of 131.70 per cent. Once

${ }^{20}$ For the Flemish Consumer Price Index, see John Munro, 'Wage-Stickiness, Monetary Changes, and Real Incomes in Late-Medieval England and the Low Countries, 1300 - 1500: Did Money Matter?' Research in Economic History, 21 (2003), pp. 185-297, Table 1, p. 231.

${ }^{21}$ They are discussed, in depth, in Spufford, 'Debasement of the Coinage’, pp. 63-85. 
more, the actual extent of inflation, as drastic as it may appear, was considerably less: from the Flemish CPI of 120.31 in 1484 to 231.87 in 1490 , for an overall increase of 92.73 percent. $^{22}$

Part B of this table demonstrates that the monetary experience of England (for the far longer span of 1351 to 1542) did not differ from the Flemish. Again in the case of virtually all the debasements - in 1351, 1412, 1464, 1526, and 1542 - the increase in the Consumer Price Index over the subsequent two years was less than the increase in the coined value of the traite. ${ }^{23}$ The debasements of 1351, 1412, and 1526 were all defensive debasements (see below); and the one exception, for these years, followed by a much more extensive rise in prices was Henry VIII's first debasement, of 1526; but that may have been due to silver influxes from the peak of the Central European mining booms. ${ }^{24}$ Once again that rise in the English CPI (base 1451-75=100) - from 137.12 in 1526 to 184.36 in 1528 - was then followed by a sharp fall (of 15.50 percent), to 155.80 in 1529 . Even more remarkable is the statistically insignificant rise in prices - just 3.38 percent - following the commencement of Henry VIII's Great Debasement, in 1542. ${ }^{25}$ All these monetary and corresponding price data confirm the proposition that short-term inflation was less, often considerably much less, than would be expected by the quantity theory of money and less than the nominal gains that both the prince and bullion-supplying merchants would derive from participating in the debasements (at least in the later medieval Low Countries and England).

\section{Debasement and inflation through the prism of the modern quantity theories of money}

Furthermore, even the modern and properly formulated version of the Quantity Theory of Money

${ }^{22}$ See n. 20 above.

${ }^{23}$ The English CPI statistics are taken from my revisions of E. Henry Phelps Brown and Sheila V. Hopkins, 'Seven Centuries of the Prices of Consumables Compared with Builders' Wage-Rates', Economica, New Series, 23: no. 92 (Nov. 1956), pp. 296-314: reprinted in E.H. Phelps Brown and S. V. Hopkins, A Perspective of Wages and Prices (London: Methuen, 1981), pp. 13-59. My revised series is based on the price data contained in their working papers, in Box Ia:324, in the Archives of the British Library of Political and Economic Science (London School of Economics).

${ }^{24}$ See Munro, 'Coinages of Henry VIII', pp. 423-76; John Munro, 'The Monetary Origins of the "Price Revolution:” South German Silver Mining, Merchant-Banking, and Venetian Commerce, 14701540', in Dennis Flynn, Arturo Giráldez, and Richard von Glahn (eds.), Global Connections and Monetary History, 1470 - 1800 (Aldershot and Brookfield, Vt: Ashgate Publishing, 2003), pp. 1-34.

25 Ibid. Edward IV's aggressive debasement of 1464, reducing the silver content by 20.0 percent and raising the silver traite by 25.0 percent, was followed by a 19.81 percent rise in the CPI, by 1466: to 105.51; but the CPI then began to fall over the ensuing decade, reaching a nadir of 84.62 in 1477, for a decline of 19.80 percent, indicating the deflationary forces of the current 'bullion famine'. 
should indicate why inflations were rarely if ever proportional to the extent of the coinage debasements (as interpreted by the previously cited formula). Consider the version based on the income velocity of money, a refinement of the classic Fisher Identity: M.V = P.y, in which $\mathrm{M}$ is the stock of coined money, $\mathrm{V}$ is the income velocity of money, $\mathrm{P}$ is the Consumer Price Index and ' $\mathrm{y}$ ' is net national income $(\mathrm{NNI}=\mathrm{NNP})$. We may predict that increasing the stock of such money $\mathrm{M}$ - here, by a coinage debasement - would likely have led to an increase in output (for reasons noted below), in terms of net national product and net national income, but also to some decrease in the income velocity, and to some inflation. The extent of inflation (rise in P) would have been offset - to some unpredictable degree - by countervailing changes in V and ' $y$ ' (NNI).

Those consequences may be better understood in terms of the alternative Cambridge Cash Balances equation: $\mathrm{M}=\mathrm{P} . \mathrm{k} . \mathrm{y}$, in which the variable ' $\mathrm{k}$ ' represents that proportion of net national income that the public chooses to hold in the form of cash balances, thereby deliberately foregoing investment income from using such cash. The Keynesian assumption, given an increase in the effective circulating money supply, and with no changes in Liquidity Preference, is that the rate of interest should decline (as it did in the sixteenth century), with two likely consequences: (1) an increase in real outputs ('y') and capital investments; and (2) an increase in ' $k$ ', with the reduction in the opportunity cost of holding cash balances, as expressed in the interest rate. ${ }^{26}$ Since ' $\mathrm{k}$ ' and $\mathrm{V}$ are mathematical reciprocals, that would mean a reduction in the income velocity of money - and that reduction also reflected the decreased need to economize on the use of money. ${ }^{27}$

One possible exception might seem to be the Henrician Great Debasement of 1542-1551, when the overall debasement of the silver coinage, by an astonishing 83.1 percent, should have provoked a veritable 'flight from money' - to convert debased coin into goods as soon as possible. Presumably doing so ought to have increased the income velocity of money and thus fuelled the very inflation that merchants had sought

${ }^{26}$ For declining rates of interest, both nominal and real, in the sixteenth century, see Sidney Homer and Richard Sylla, A History of Interest Rates, $3^{\text {rd }}$ rev. edn (New Brunswick NJ: Rutgers University Press, 1996), pp. 89-143, especially Table 11 (pp. 137-38), and Chart 2 (p. 140); and Herman Van der Wee, The Growth of the Antwerp Market and the European Economy (fourteenth-sixteenth centuries), 3 vols. (The Hague: Martinus Nijhoff, 1963), vol. 1: Statistics, Appendix 45/2, pp. 525-7.

${ }^{27}$ For evidence that increases in the money supply usually did lead to a fall in the income velocity of money, except during the sixteenth-century Price Revolution era, see Nicholas J. Mayhew, 'Population, Money Supply, and the Velocity of Circulation in England, 1300 - 1700', Economic History Review, 48:2 (May 1995), pp. 238-57. 
to avoid. Nevertheless, while we find that the coined value of the English silver traite rose, overall, by 492.00 percent (by April 1551) - in exact mathematical correspondence to the 83.1 percent reduction in the penny’s silver content - the English CPI rose by only 51.73 percent over this period: from 174.94 in 1542 to just 265.26 in 1553-54. ${ }^{28}$ This historical evidence, for both England and Flanders, should provide sufficient proof that merchants as well as princes could have expected often substantial real gains from participating in coinage debasements, though both the merchants and the prince’s government would always have been well advised to spend their newly acquired coins quickly.

The accompanying Table 3 (appendix) demonstrates the gains that Duke Philip the Good earned from the debasements that he undertook from his accession in 1419 - not only in Flanders, but also in his other territories of Namur, Holland-Zeeland, Hainaut and Brabant - up to 1433-34, when he decided to terminate his debasement policy and impose a unification of monetary reform of the now united Burgundian Low Countries. With that reform, Philip the Good agreed not to debase his coinages again, for thirty years, not without the consent of his Estates; and in doing so, he accepted a very modest seigniorage. ${ }^{29}$ His next debasement, in 1466-67, undertaken with the consent of his Estates, was for defensive reasons, as explained in the following section. ${ }^{30}$

\section{Motives for pre-modern coinage debasements, II: a monetary defence against Gresham's Law}

Oresme's hostile view of the motives of so many medieval princes in 'manipulating' their coinages took no notice of the possible defensive motives of those princes in being occasionally forced to debase their coinages. Consider, that if aggressive, profit-seeking coinage debasements depended for their complete success on luring bullion from foreign lands, then the rulers of those victimized neighbouring principalities would understandably have reacted with retaliatory debasements. A particular problem arose when one prince sought to counterfeit the coins of his neighbours: i.e., by closely imitating such coins with issues that

${ }^{28}$ The fine silver content of the English penny from 1526 to 1542 was 0.639 gram; by April 1551, during the worst phase of the Great Debasement (ending in June 1553), the penny contained only $0.169 \mathrm{~g}$ fine silver. The corresponding traite value of fine silver rose from £6.517 to £38.568 per kilogram over this period. See Munro, ‘Coinages of Henry VIII’, Table 1, pp. 457-463.

${ }^{29}$ Munro, Wool, Cloth, and Gold, pp. 100-03, 168-71, Tables J-K, pp. 208-11; Peter Spufford, Monetary Problems and Policies in the Burgundian Netherlands, 1433-1496 (Leiden: Brill, 1970), chapter 3, 'Currency', pp. 55 - 73; chapter 4, 'La guerre monétaire’, pp. 74 - 129.

${ }^{30}$ See Munro, Wool, Cloth, and Gold, pp. 157-71; below, n. 39. 
contained a lesser quantity of precious metals. One of the most prominent and flagrant examples were those of the dukes of Burgundy in striking inferior imitations of the English gold nobles, with varying degrees of success, from 1388 to $1428 .{ }^{31}$

At the same time, the counts of Flanders and their successor dukes of Burgundy were often victims of similar counterfeiting from their own neighbours. ${ }^{32}$ For example, Duke Philip the Good's debasement of the Flemish silver coinage, at the Ghent mint in November 1428, portrayed above as an aggressive, profitseeking venture - as it most certainly was - was partly undertaken as a defensive reaction against the issues of counterfeits of the Flemish silver double groot that the French Dauphin Charles (later Charles VII) had implemented, from June 1428, in his mint of Tournai, a French enclave within Flanders. That debasement soon reduced Ghent's silver coinage output to virtually nothing. During the entire Michaelmas year of 142829, the Ghent mint struck only 4,598.7 marcs argent-le-roy (1,126.54 kg fine silver); in the following year, after the November 1428 debasement, the Ghent mint output soared to 72,460.7 marcs argent-le-roy $\left(=17,734.97 \mathrm{~kg}\right.$ fine silver), with the consequent seigniorage revenues listed in Table $3 .^{33}$

Not surprisingly most late-medieval coinage ordinances that implement debasements justified them on purely defensive grounds, and many were indeed undertaken for such a combination of defensive and aggressive (profit-seeking) motives. The particular defensive problem that such foreign domestic debasements produced is known today as Gresham’s Law: commonly stated as ‘bad money drives out good money’. The essence of this so-called law is based on the principle that, so long as coins circulated only by tale (face-value), no rational, informed person would spend higher-silver content coins of the same face value. Instead, most merchants would melt down and hoard the better coins as bullion, or sell them for export to foreign mints, especially those engaged in debasements. Indeed that principle was well known long before the actual Thomas Gresham (1519-1579), and can be found in so many French and Flemish mint documents from the

${ }^{31}$ John Munro, ‘A Maze of Medieval Monetary Metrology: Determining Mint Weights in Flanders, France and England from the Economics of Counterfeiting, 1388 - 1469', The Journal of European Economic History, 29:1 (Spring 2000), pp. 173-99; Munro, Wool, Cloth, and Gold, pp. 43-88, Table F, pp. 202-03.

32 See many fifteenth-century examples in John Munro, 'An Aspect of Medieval Public Finance: The Profits of Counterfeiting in the Fifteenth-Century Low Countries', Revue belge de numismatique et de sigillographie, 118 (1972), pp. 127-48.

${ }^{33}$ Munro, Wool, Cloth, and Gold, pp. 70-84. 
mid-fourteenth century. ${ }^{34}$

Gresham's Law pertained, however, not just to the circulation of fraudulent foreign coins (and thus especially counterfeits) but also to defective domestic coins, whose circulation provided an even more powerful defensive reason to undertake periodic coinage debasements. Many domestic coins had become defective through deliberate fraud, even apart from domestic counterfeiting: in particular from clipping and 'sweating' coins. The former was the common practice of using shears to clip off portions of the edges of coins; and the latter was the practice of shaking together a group of coins inside a leather bag, so that the resulting friction would remove some precious metal from the coins, which would then adhere to the sides of the bag, later to be scraped and removed as bullion. The previously discussed imperfect techniques of hammered coinages readily explain why such tampering could take place without being readily observed. Indeed, the only solution to this problem was the later introduction of steam-powered machinery to stamp coins with perfectly rounded and milled edges. ${ }^{35}$ Finally, most coins lost their precious metals over time, without any such fraud, through perfectly normal circulation - from both physical and chemical erosion even though the coins had always been alloyed with copper as a hardening agent. Low-denomination silver coins generally suffered a greater precious-metal loss than did higher denomination silver and gold coins, because they had a far higher circulation velocity. ${ }^{36}$

The inevitable consequence of such wear and tear and other physical losses, from clipping and sweating, was of course to eliminate the aforementioned agio or premium that coin normally commanded over bullion, so that the prince's mint ceased to receive bullion. ${ }^{37}$ Faced with that prospect, most princes, legitimately concerned about protecting the operation of their mints, and maintaining the integrity of their

${ }^{34}$ See John Munro, 'Gresham’s Law', in Joel Mokyr (ed.), The Oxford Encyclopedia of Economic History, 5 vols. (Oxford and New York: Oxford University Press, 2003), vol. 2, pp. 480-1; Munro, Wool, Cloth and Gold, pp. 11-41. Sir Thomas Gresham was a merchant-banker and royal agent in Antwerp, and financial advisor to Queen Elizabeth I; he was also the founder of the Royal Exchange, in London (1565).

35 See Sargent and Velde, Big Problem of Small Change, pp. 45-68

36 See Charles Patterson, 'Silver Stocks and Losses in Ancient and Medieval Times', Economic History Review, 2nd ser. 25:2 (May 1972), pp. 205-35; N. Mayhew, 'Numismatic Evidence and Falling Prices in the Fourteenth Century', Economic History Review, 2nd ser., 27:1 (Feb. 1974), pp. 1-15; Albert Feavearyear, The Pound Sterling: A History of English Money, 2nd rev. edn. by E. Victor Morgan (Oxford: Clarendon Press, London, 1963), pp. 1-45.

${ }^{37}$ For these and related problems with medieval Venetian coinages, see Lane and Mueller, Money and Banking, vol. 1, pp. 24-35, 380-415. 
circulating coinage and money supplies, would have been forced to undertake a defensive debasement: to reduce the silver contents of their newly issued coins to at least the level found in currently circulating coin and thus to restore the agio on their coinages, in order to reactivate their mints. ${ }^{38}$

\section{The test for motives in medieval coinage debasements: the relative seigniorage rates}

Even when the observable economic circumstances and mint ordinances for implementing coinage debasement reflect a both defensive and aggressive motives for debasement, the predominant motive was readily observable in the seigniorage rates: high, for aggressive profit-seeking; and low for purely defensive protection of the mints. The latter was based on the obvious principle that the lower was the mintage fee, the higher would be the mint price for bullion offered to merchants.

As already noted, for example, in Duke Philip the Good's debasement of the Flemish silver coinage in November 1428, the seigniorage was increased by 50 percent, from $4 \mathrm{~d}$ to $6 \mathrm{~d}$ per marc argent le roy. But subsequently, when the coinages of Flanders and neighbouring Burgundian territories were unified and reformed in 1433-34, the seigniorage was reduced by two thirds: to just $2 \mathrm{~d}$ per marc ( 0.69 percent of the traite). In his next coinage change of May 1466, a purely defensive coinage debasement, Philip reduced the seigniorage even further: to $1.5 \mathrm{~d}$ per marc ( $=0.45$ percent of the traite). Over this period, from 1433 to 1466, the total mintage fees were reduced from 6.60 percent to 4.24 percent of the traite per marc, so that the mint price for merchants' bullion rose from 93.40 percent to 95.86 percent of that traite value. But when his successor Charles the Bold - killed at the Battle of Nancy in January 1477 - undertook a drastic and aggressive debasement of the silver coinage in October 1474, he tripled the seigniorage to 6d per marc argent le roy and necessarily reduced the mint price to 94.08 percent of that traite value. ${ }^{39}$

As is indicated by Philip the Good's monetary reform of 1433-34, not all medieval coinage alterations

${ }^{38}$ On this, see Feavearyear, Pound Sterling, pp. 1-45. For early-modern Europe, see very similar arguments in Debra Glassman and Angela Redish, 'Currency Depreciation in Early Modern England and France', Explorations in Economic History, 25:1 (1988), pp. 75-97. For the importance of both coinage 'wear and tear' and Gresham's law in Henry VIII's defensive debasement of 1526, see Munro, 'Coinages of Henry VIII’, pp. 437-50.

${ }^{39}$ Munro, Wool, Cloth, and Gold, Table G, p. 204. An even more glaring contrast can be found with the coinages of Henry VIII. With his purely defensive debasement of Nov. 1526, total mintage fees (seigniorage and brassage) amounted to 2.22 percent of the silver traite; at the peak of the Great Debasement in April 1546, they amounted to 61.11 percent of the traite; but in the reformed coinages of June 1557 and Nov. 1560, they were only 2.50 percent of the traite. See Munro, 'Coinages of Henry VIII', Table 1, part 3, pp. 462-63. 
were debasements. The opposite is known as a 'strengthening' of the coinage, for which the French term is even better: renforcement. In this monetary reform, Duke Philip augmented the fine silver content of the double groot coin from $1.522 \mathrm{~g}$ to $1.629 \mathrm{~g}$ fine silver (an increase of 7.04 percent), thereby reducing the traite value of the marc argent-le-roy from $£ 1.284$ to $£ 1.200$ groot Flemish (from $£ 5.474$ to $£ 5.116$ per kilogram pure silver: a reduction of 6.54 percent). Despite the drastic reduction in the seigniorage, as noted above, the Flemish mint price for bullion was still necessarily also reduced: from $£ 1.200$ to $£ 1.138$ groot Flemish per marc argent-le-roy, but with the prospect of deflation and thus of a higher-valued coinage. ${ }^{40}$

For obvious reasons, coinage renforcements were much more difficult to implement than were debasements and were undertaken only when the prince had decided that a restoration of his prestige demanded such a corresponding coinage restoration - since, as stressed earlier, coinage such an important symbol of sovereignty. In Flanders, the previous renforcement was undertaken by Philip the Good's grandfather, Philip the Strong (Philippe le Hardi), in 1389-1390 (with a reduction in the traite from £5.337 to $£ 4.050$ per kilogram of pure silver). ${ }^{41}$

Especially because defensive debasements took place more often than did aggressive debasements, and certainly far, far more often than renforcements, for the variety of reasons earlier examined, most European silver coinages experienced a more or less continuous diminution in their precious metal contents until modern times. The best documented example is England, which practised chiefly defensive debasements (except for the aforesaid 'Great Debasement' during the reigns of Henry VIII and Edward VI. From the first fully documented coinage, in 1257 (Henry III), to Elizabeth I's recoinage of 1602, the pure silver content of the penny was reduced from $1.337 \mathrm{~g}$ to just $0.464 \mathrm{~g}$ (only 34.70 percent as much). By February 1817, when the final change in issues of silver penny took place, that precious metal content had diminished by another 6.06 percent, to $0.471 \mathrm{~g}^{42}$

${ }^{40}$ Munro, Wool, Cloth, and Gold, pp. 100-03; Table C, pp. 198-99; Table G, p. 204. The consequent deflation, given the contraction of the coined money supply was far steeper: by 22.39 percent with a fall in the CPI from 139.092 in 1433 to 108.046 in 1435 (98.777 in 1436).

${ }^{41}$ Munro, Wool, Cloth, and Gold, pp. 43-63, Table C, pp. 198-99; Table G, p. 204; John Munro, 'Mint Policies, Ratios, and Outputs in England and the Low Countries, 1335-1420: Some Reflections on New Data', The Numismatic Chronicle, 141 (1981), pp. 71-116.

${ }^{42}$ Feavearyear, Pound Sterling, Appendix III:ii, p. 439; Christopher Challis, 'Appendix 2: Mint Contracts', in Christopher Challis (ed.)., A New History of the Royal Mint (Cambridge; Cambridge University Press, 1992), pp. 699-758. 


\section{Were medieval debasements undertaken to counteract monetary scarcities?}

The final question to be posed is closely related: did medieval rulers ever undertake defensive debasements as deliberately formulated monetary policies to 'reflate’ and expand the supply of circulating coins in time of perceived monetary scarcities, especially during the so-called 'bullion famines' of the later Middle Ages? ${ }^{43}$ That is a complex question that requires a separate study, but the short and simple answer is no: there is no evidence that any medieval rules undertook any such deliberate monetary policies, other than the defensive debasements just discussed, and for the reason discussed here.

Nevertheless, one cannot ignore the conclusions of the recently published monograph, The Big Problem of Small Change, which the Nobel-prize winning economist Thomas Sargent co-authored with François Velde. They contend that 'the motive for most debasements was to maintain adequate supplies of coins, not to raise government revenues', and more specifically such debasements were generally designed to remedy the chronic, pervasive shortages of 'small change'. ${ }^{44}$ These petty coins, commonly known as billon or vellon coins, were normally those with a nominal or face value of less than penny, though by the sixteenth century the combination of debasements and the inflation of the Price Revolution era (from ca. 1520) meant, in some countries (e.g., France and Italy) that coins in denominations higher than a penny were then considered to be billon coins. Before the 1540s, such coins had always contained at least some silver, even if largely copper. ${ }^{45}$ Whether or not such shortages of billon were truly chronic and pervasive is subject to considerable debate, even if the proportions of medieval coinages struck in denominations under one penny

\footnotetext{
${ }^{43}$ See Spufford, Money and Its Use, pp. 339-63.
}

${ }^{44}$ Sargent and Velde, Big Problem of Small Change, pp. 5, 7-8, 10, 40, 152, 187, 261, 321, 324. See in particular, p. 261 (and n. 1): 'We interpret many of these debasements as having been designed to cure shortages of small change, not primarily to gather seigniorage'. They admit that fiscal motives did predominate in Henry VIII’s Great Debasement.

45 The Habsburg Netherlands were the first to strike all-copper coins in 1543; France followed in 1577; Habsburg Spain in 1599; and England only in 1672. See H. Enno Van Gelder and Marcel Hoc, Les monnaies des Pays-Bas bourguignons et espagnols, 1434-1713: Répertoire générale (Amsterdam, J. Schulman, 1960); Van der Wee, Antwerp Market, vol. I, pp. 123-35; Frank Spooner, The International Economy and Monetary Movements in France, 1493-1725 (Paris, 1956; Cambridge, MA: Harvard University Press, 1972, for the English edn), Appendix A, p. 332; Earl J. Hamilton, American Treasure and the Price Revolution in Spain, 1502 - 1650 (Cambridge, Mass.: Harvard University Press, 1934), pp. 49-64; Christopher Challis, 'Lord Hastings to the Great Silver Recoinage, 1464 - 1699', in C. Challis (ed.), A New History of the Royal Mint (Cambridge: Cambridge University Press, 1992), pp. 365-78; and Appendix 1: Mint Output, 1220-1985, p. 689. 
were indeed always small. ${ }^{46}$ Nevertheless Sargent and Velde never prove their case with any concrete evidence of specific debasements. In particular, they cannot demonstrate that such debasements were ever undertaken to increase the supply of just such petty billon coins. For the evidence of all available mint accounts in medieval Europe demonstrate that debasements of the silver coinages almost always affected all denominations alike, and not just those below the penny in value - thus including the still silver-based billon coins. ${ }^{47}$ Indeed, had such rulers debased only the petty coins, while leaving higher denomination silver coins intact, market forces would have either increased the latter's value, by adding a premium, or would have promoted the export of 'full-bodied' coins, had they remained undervalued. ${ }^{48}$ With rare exceptions, therefore, late-medieval and early-modern European debasements were undertaken for either the aggressive or defensive motives that have been explored in this study. They were rarely, if ever, undertaken to replenish stocks of the coined money supply - i.e., independent of the reasons explored here. ${ }^{49}$

${ }^{46}$ John Munro, 'Deflation and the Petty Coinage Problem in the Late-Medieval Economy: The Case of Flanders, 1334 - 1484', Explorations in Economic History, 25:4 (October 1988), pp. 387-423: estimating that normally only about one percent of the total amount of silver coined in the Burgundian Low Countries (1384-1482) was in petty coins known, as mites (= 1/24 of a penny): single and double.

${ }^{47}$ One exception that Sargent and Velde do not note was the Burgundian-Flemish monetary ordinance of 31 August 1457, during an era of very low mint outputs. It required the mint to strike a greater number of billon coins known as courtes or double-mites (=1/12th of a penny groot) from the alloyed marc: 240 courtes in place of the previously required 216 per marc. Nevertheless, in the quinquennium 1456-60, only $51.302 \mathrm{~kg}$ of fine silver were minted - compared to 112 times as much in 1426-30: 5,724.645 kg. See Munro, 'Petty Coinage', Table 3, p. 396.

48 See n. 14 above; and especially José Antonio Mateos Royo, 'The Burdens of Tradition: Debasements, Coinage Circulation and Mercantilist Public Policy Debates in Seventeenth-Century Aragon', in John Munro, ed., Money in the Pre-Industrial World: Bullion, Debasements and Coin Substitutes (London: Pickering \& Chatto Ltd., 2012), pp. 111-28.

${ }^{49}$ This subject is investigated at greater depth and in far more detail in John Munro, 'Coinage Debasements in Burgundian Flanders, 1384-1482: Monetary or Fiscal Policies', in David Nicholas, Bernard S. Bachrach, and James M. Murray, eds., Comparative Perspectives on History and Historians: Essays in Memory of Bryce Lyon (1920 - 2007), Medieval Institute Publications, Western Michigan University (Kalamazoo, MI: The Medieval Institute, 2012), pp. 314-60; and also in Munro, 'Coinages of Henry VIII' (see n. 12 above). 
Table 1.

\section{Double Groot}

Value in money-of-account ${ }^{\mathrm{a}}$

Fineness ${ }^{b}$

in argent-le-roy (AR)

Weight (Taille) ${ }^{\mathrm{c}}$ in grams

Fine silver content AR in g.

Pure silver content in $\mathrm{g}$.

Traite per marc ${ }^{\mathrm{d}}$

argent-le-roy

Division of the Traite Value per marc argent-le-roy

Brassage

Seigniorage

Total Mint Charges (of the above)

Mint Price: for merchants' bullion

Traite per Marc argent-le-roy

${ }^{a}$ Values in money-of-account:

${ }^{\mathrm{b}}$ Fineness:

${ }^{\mathrm{c}}$ Weight:

${ }^{\mathrm{d}}$ Traite per marc:

Flemish Coinage Debasement: The Mint Ordinances of June 1418 and November 1428

\section{June 1418}

2d groot Flemish

6 deniers $\mathrm{AR}=$

68 cut to the marc

$\frac{68.0 \times 2 \mathrm{~d} .}{6 / 12}=\frac{136 \mathrm{~d}}{0.5}=$

\section{Value in Number groot Flemish of coins}

$\begin{array}{r}1 \mathrm{~s} 2 \mathrm{~d} \\ 4 \mathrm{~d} \\ \hline\end{array}$

$4 \mathrm{~d}$

1s $6 \mathrm{~d}$

$\underline{21 s 2 d}$

22s 8d

1 penny or $1 \mathrm{~d}$ groot $=24$ mites $($ mijten $)=12 \mathrm{~d}$ or 1 s parisis

$12 \mathrm{~d}$ groot $=1 \mathrm{~s}$ (sou, sol, schelling); 1 livre or pond $(£ 1$ pound) $=20$ shillings $=240 \mathrm{~d}$ (pence)

reckoned out of 12 deniers argent-le-roy, with 24 grains per denier: 23/24 or 95.833\% pure reckoned in terms of the taille or number cut from the marc de Troyes of 8 onces: $244.753 \mathrm{~g}$.
$44.44 \%$ fine $42.59 \%$ pure

3.573 grams

$1.588 \mathrm{~g}$.

$1.522 \mathrm{~g}$.

25s $8 d$ 6mites

$\frac{68.5 \times 2 \mathrm{~d} .}{0.444}=\underline{137 \mathrm{~d}}=$

Value in Number of groot Flemish coins

Percentage of the traite

$100.00 \%$

$\begin{array}{rr}1 \mathrm{~s} 2 \mathrm{~d} 6 \mathrm{~m} & 7 \\ 6 \mathrm{~d} 0 \mathrm{~m}\end{array}$

1s $8 \mathrm{~d} 6 \mathrm{~m}$

$101 / 8$

\section{$6.57 \%$}

$\underline{93.43} \%$

$4.62 \%$

$1.95 \%$

24s 0d 0m

$1541 / 8$ 
Table 2:

$$
\text { Part A: Relationships between the debasements of the Flemish }
$$

silver penny groot and changes in the Consumer Price Index in Flanders, 1409 - 1484

Consumer Price Index: base 1451-75 = 100

\begin{tabular}{|c|c|c|c|c|c|c|c|c|c|}
\hline Years & $\begin{array}{l}\text { Silver } \\
\text { Content of } \\
\text { the Flemish } \\
\text { silver penny } \\
\text { in grams }\end{array}$ & $\begin{array}{l}\text { percentage } \\
\text { change } \\
\text { from } \\
\text { previous } \\
\text { coinage }\end{array}$ & $\begin{array}{l}\text { Value of } \\
1 \text { kg fine } \\
\text { silver in } \\
£ \text { groot } \\
\text { Flemish }\end{array}$ & $\begin{array}{l}\text { percentage } \text { Year } 1 \\
\text { change } \\
\text { from } \\
\text { previous } \\
\text { coinage }\end{array}$ & Year 3 & & $x$ in & $\begin{array}{l}\text { Price } \\
\text { Index in } \\
\text { Year } 3\end{array}$ & $\begin{array}{l}\text { Percentage } \\
\text { Change } \\
2 \text { years }\end{array}$ \\
\hline 1409 & 1.182 & & 3.524 & & & & & & \\
\hline 1416 & 0.958 & $-18.95 \%$ & 4.349 & $23.39 \%$ & 1416 & 1418 & 118.916 & 92.239 & $-22.43 \%$ \\
\hline 1418 & 0.850 & $-11.30 \%$ & 4.903 & $12.75 \%$ & 1418 & 1420 & 92.239 & 98.118 & $6.37 \%$ \\
\hline 1428 & 0.749 & $-11.91 \%$ & 5.566 & $13.53 \%$ & 1428 & 1430 & 112.317 & 125.849 & $12.05 \%$ \\
\hline 1433 & 0.814 & $8.80 \%$ & 5.116 & $-8.09 \%$ & 1433 & 1435 & 139.210 & 108.046 & $-22.39 \%$ \\
\hline 1466 & 0.703 & $-13.67 \%$ & 5.926 & $15.83 \%$ & 1466 & 1468 & 95.930 & 96.153 & $0.23 \%$ \\
\hline 1467 & 0.677 & $-3.77 \%$ & 6.158 & $3.92 \%$ & 1467 & 1469 & 102.146 & 96.000 & $-6.02 \%$ \\
\hline 1474 & 0.597 & $-11.79 \%$ & 6.981 & $13.37 \%$ & 1474 & 1476 & 108.208 & 92.370 & $-14.64 \%$ \\
\hline 1477 & 0.522 & $-12.50 \%$ & 7.979 & $14.29 \%$ & 1477 & 1479 & 98.775 & 149.327 & $51.18 \%$ \\
\hline 1482 & 0.466 & $-10.71 \%$ & 8.936 & $12.00 \%$ & 1482 & 1484 & 193.932 & 120.307 & $-37.96 \%$ \\
\hline
\end{tabular}


Part B: Relationships between the debasements of the English sterling silver penny and changes in the Consumer Price Index in England, 1346 - 1544

Consumer Price Index: base 1451-75 = 100

\begin{tabular}{|c|c|c|c|c|c|c|c|c|c|}
\hline Years & $\begin{array}{l}\text { Silver } \\
\text { Content of } \\
\text { the English } \\
\text { silver penny } \\
\text { in grams }\end{array}$ & $\begin{array}{l}\text { percentage } \\
\text { change } \\
\text { from } \\
\text { previous } \\
\text { coinage }\end{array}$ & $\begin{array}{l}\text { Value of } \\
1 \text { kg fine } \\
\text { silver in } \\
\text { £ sterling } \\
\text { English }\end{array}$ & $\begin{array}{l}\text { percentage } \\
\text { change } \\
\text { from } \\
\text { previous } \\
\text { coinage }\end{array}$ & Year 1 & Year 3 & $\begin{array}{c}\text { Price } \\
\text { Index in } \\
\text { Year } 1\end{array}$ & $\begin{array}{c}\text { Price } \\
\text { Index in } \\
\text { Year } 3\end{array}$ & $\begin{array}{c}\text { Percentage } \\
\text { Change } \\
2 \text { years }\end{array}$ \\
\hline 1346 & 1.199 & & 3.476 & & & & & & \\
\hline 1351 & 1.079 & $-10.00 \%$ & 3.862 & $11.11 \%$ & 1351 & 1353 & 128.695 & 132.567 & $3.01 \%$ \\
\hline 1412 & 0.899 & $-16.67 \%$ & 4.634 & $20.00 \%$ & 1412 & 1414 & 103.557 & 107.673 & $3.97 \%$ \\
\hline 1464 & 0.719 & $-19.99 \%$ & 5.793 & $25.00 \%$ & 1464 & 1466 & 88.062 & 105.511 & $19.81 \%$ \\
\hline 1526 & 0.639 & $-11.11 \%$ & 6.517 & $12.50 \%$ & 1526 & 1528 & 137.120 & 184.364 & $34.45 \%$ \\
\hline 1542 & 0.491 & $-23.14 \%$ & 8.479 & $30.11 \%$ & 1542 & 1544 & 174.939 & 180.847 & $3.38 \%$ \\
\hline
\end{tabular}

\section{Sources:}

J. Munro, Wool, Cloth, and Gold: The Struggle for Bullion in Anglo-Burgundian Trade, 1340 - 1478 (Brussels and Toronto: 1973), Table C, p;p. 198-99; Table D, p. 200; Table F, pp. 202-03; Table G, p. 204; Table K, p. 211. See also the list of mint-account sources on pp. $193-97$.

A. Feavearyear, The Pound Sterling: A History of English Money, 2nd rev. edn. by E. V. Morgan (Oxford: Clarendon Press, London, 1963), Appendix III:ii, p. 439; C. Challis, 'Appendix 2: Mint Contracts', in C. Challis (ed.)., A New History of the Royal Mint (Cambridge; Cambridge University Press, 1992), pp. 699-758.

J. Munro, 'Wage-Stickiness, Monetary Changes, and Real Incomes in Late-Medieval England and the Low Countries, 1300 - 1500: Did Money Matter?' Research in Economic History, 21 (2003), pp. 185-297, Table 1, p. 231; J. Munro, 'Builders' Wages in Southern England and the Southern Low Countries, 1346 -1500: A Comparative Study of Trends in and Levels of Real Incomes', in Simonetta Cavaciocchi, ed., L'Edilizia prima della rivoluzione industriale, secoli XIII-XVIII, Atti delle "Settimana di Studi” e altri convegni, no. 36, Istituto Internazionale di Storia Economica "Francesco Datini” (Florence: Le Monnier, 2005), pp. 1013-76. 
E.H. Phelps Brown and S.V. Hopkins, 'Seven Centuries of the Prices of Consumables Compared with Builders' Wage-Rates', Economica, New Series, 23: no. 92 (Nov. 1956), pp. 296-314: reprinted in E.H. Phelps Brown and S. V. Hopkins, A Perspective of Wages and Prices (London: Methuen, 1981), pp. pp. 13-59. Revised series based on the price data contained in their working papers, in Box Ia:324, in the Archives of the British Library of Political and Economic Science (London School of Economics). 
Table 3. Seigniorage Revenues from Minting Gold and Silver Coins in the

Burgundian Low Countries under Duke Philip the Good, 1419- 1433

in pounds groot Flemish

$\begin{array}{crrr}\begin{array}{c}\text { Year } \\ \begin{array}{c}\text { Michaelmas } \\ \text { ending in }\end{array}\end{array} & \text { GOLD } & \text { SILVER } & \text { TOTAL } \\ & \mathfrak{f} \text { groot } & \text { f groot } & \text { f groot } \\ \mathbf{1 4 2 0} & 0 & 965 & 965 \\ \mathbf{1 4 2 1} & 5 & 923 & 928 \\ \mathbf{1 4 2 2} & 43 & 1,130 & 1,173 \\ \mathbf{1 4 2 3} & 2 & 848 & 850 \\ \mathbf{1 4 2 4} & 23 & 808 & 831 \\ \mathbf{1 4 2 5} & 103 & 353 & 456 \\ \mathbf{1 4 2 6} & 2,156 & 226 & 2,382 \\ \mathbf{1 4 2 7} & 3,761 & 48 & 3,809 \\ \mathbf{1 4 2 8} & 692 & 123 & 815 \\ \mathbf{1 4 2 9} & 1,547 & 2,035 & 3,582 \\ \mathbf{1 4 3 0} & 351 & 1,316 & 1,667 \\ \mathbf{1 4 3 1} & 1,656 & 283 & 1,939 \\ \mathbf{1 4 3 2} & 5,088 & 55 & 5,143 \\ \mathbf{1 4 3 3} & 5,459 & 14 & 5,473 \\ & & & \mathbf{3 0 , 0 1 3} \\ \text { Total } & \mathbf{2 0 , 8 8 6} & \mathbf{9 , 1 2 7} & \\ \mathbf{1 4} \text { yr mean } & 1,491.857 & & 2,143.786\end{array}$

\section{Source:}

John H. Munro, Wool, Cloth, and Gold: The Struggle for Bullion in Anglo-Burgundian Trade, 1340 - 1478 (Brussels: Editions de l'Université de Bruxelles; and Toronto: University of Toronto Press, 1973), Table III, p. 83; Appendix I, Table H, p. 205; Table J, p. 207. See pp. 193-96 for the archival sources of the mint accounts used for this table. 


\section{List of References:}

Blanchet, Adrien; and Alphonse Dieudonné (eds.), Manuel de numismatique française, 2 vols. (Paris: Ricard, 1916).

Bridrey, Émile, La Théorie de la monnaie au XIVe siècle: Nicole Oresme: étude d'histoire des doctrines et des faits économiques (Paris: Girard et Brière, 1906).

Challis, Christopher, 'Lord Hastings to the Great Silver Recoinage, 1464 - 1699', in C. Challis (ed.), A New History of the Royal Mint (Cambridge: Cambridge University Press, 1992), pp. 365-78.

Challis, Christopher, 'Appendix 2: Mint Contracts', in C. Challis (ed.)., A New History of the Royal Mint (Cambridge; Cambridge University Press, 1992), pp. 699-758.

Feavearyear, Albert, The Pound Sterling: A History of English Money, 2nd rev. edn. by E. Victor Morgan (Oxford: Clarendon Press, London, 1963).

Fournial, Etienne, Histoire monétaire de l'Occident médiéval (Paris: F. Nathan, 1970).

Gaillard, Victor (ed.), Recherches sur les monnaies des comtes de Flandre, 2 vols, (Ghent: H. Hoste, 1856).

Gandal, Neil; and Nathan Sussman, 'Asymmetric Information and Commodity Money: Tickling the Tolerance in Medieval France’, Journal of Money Credit and Banking, 29:4 (November 1997), pp. 440-457.

Girard, Albert, 'La guerre des monnaies,' Revue de synthèse 19 (1940-45), pp. 83-101.

Glassman, Debra; and Angela Redish, 'Currency Depreciation in Early Modern England and France', Explorations in Economic History, 25:1 (1988), pp. 75-97.

Grierson, Philip, 'Coin Wear and the Frequency Table,' Numismatic Chronicle, $7^{\text {th }}$ ser. 3 (1963): pp. i-xv.

Grierson, Philip, 'Weight and Coinage,' Numismatic Chronicle, $7^{\text {th }}$ ser. 4 (1964), pp. iii-xvii.

Grierson, Philip, Numismatics (Oxford: Oxford University Press, 1975).

Grierson, Philip, 'Medieval Numismatics,' in James M. Powell (ed.), Medieval Studies: An Introduction (Syracuse, Syracuse University Press, 1976), pp. 124-34.

Hamilton, Earl J.; American Treasure and the Price Revolution in Spain, 1502 - 1650 (Cambridge, Mass.: Harvard University Press, 1934).

Homer, Sidney; and Richard Sylla, A History of Interest Rates, $3^{\text {rd }}$ rev. edn (New Brunswick NJ: Rutgers University Press, 1996).

Johnson, Charles (ed.), The 'De Moneta' of Nicholas Oresme and English Mint Documents (London: Thomas Nelson and Sons, 1956).

Lane, Frederic C.; and Reinhold Mueller, Money and Banking in Medieval and Renaissance Venice, vol. 1: Coins and Moneys of Account (Baltimore and London: The Johns Hopkins University Press, 1985).

Mateos Royo, José Antonio , 'The Burdens of Tradition: Debasements, Coinage Circulation and Mercantilist Public Policy Debates in Seventeenth-Century Aragon', in John Munro, ed., Money in the Pre-Industrial World: Bullion, Debasements and Coin Substitutes (London: Pickering \& Chatto Ltd., 2012), pp. 111-28.

Mayhew, Nicholas , 'Numismatic Evidence and Falling Prices in the Fourteenth Century', Economic History Review, 2nd ser., 27:1 (Feb. 1974), pp. 1-15.

Mayhew, Nicholas J., 'From Regional to Central Minting, 1158-1464', in Christopher Challis (ed.), A New History of the Royal Mint (Cambridge: Cambridge University Press, 1992).

Mayhew, Nicholas J., 'Population, Money Supply, and the Velocity of Circulation in England, 1300 - 1700', Economic History Review, 48:2 (May 1995), pp. 238-57.

Munro, John, 'An Aspect of Medieval Public Finance: The Profits of Counterfeiting in the Fifteenth-Century Low Countries’, Revue belge de numismatique et de sigillographie, 118 (1972), pp. 127-48.

Munro, John, Wool, Cloth, and Gold: The Struggle for Bullion in Anglo-Burgundian Trade, 1340 - 1478 
(Brussels and Toronto: Éditions de l’Université de Bruxelles, 1973).

Munro, John, 'Billon - Billoen - Billio: From Bullion to Base Coinage', Revue belge de philologie et d'histoire/ Belgisch tijdschrift voor filologie en geschiedenis, 52 (1974), pp. 293-305.

Munro, John, 'Bullionism and the Bill of Exchange in England, 1272-1663: A Study in Monetary Management and Popular Prejudice', in Center for Medieval and Renaissance Studies, UCLA (ed.), The Dawn of Modern Banking (New Haven and London: Yale University Press, 1979).

Munro, John, 'Mint Policies, Ratios, and Outputs in England and the Low Countries, 1335-1420: Some Reflections on New Data', The Numismatic Chronicle, 141 (1981), pp. 71-116.

Munro, John, 'Deflation and the Petty Coinage Problem in the Late-Medieval Economy: The Case of Flanders, 1334 - 1484', Explorations in Economic History, 25:4 (October 1988), pp. 387-423.

Munro, John, Bullion Flows and Monetary Policies in England and the Low Countries, 1350 - 1500, Variorum Collected Studies series CS 355 (Aldershot, Hampshire; and Brookfield, Vermont: Ashgate Publishing Ltd., 1992).

Munro, John, ‘ A Maze of Medieval Monetary Metrology: Determining Mint Weights in Flanders, France and England from the Economics of Counterfeiting, 1388 - 1469', The Journal of European Economic History, 29:1 (Spring 2000), pp. 173-99.

Munro, John, 'Money, Wages, and Real Incomes in the Age of Erasmus: The Purchasing Power of Coins and of Building Craftsmen's Wages in England and the Southern Low Countries, 1500 - 1540', in A. Dalzell and C.G. Nauert, Jr. (eds.), The Collected Works of Erasmus: The Correspondence of Erasmus, Vol. 12: Letters 1658 - 1801, January 1526-March 1527 (Toronto: University of Toronto Press, 2003), Appendix: pp. 551-699.

Munro, John, 'The Monetary Origins of the "Price Revolution:” South German Silver Mining, MerchantBanking, and Venetian Commerce, 1470-1540’, in Dennis Flynn, Arturo Giráldez, and Richard von Glahn (eds.), Global Connections and Monetary History, 1470 - 1800 (Aldershot and Brookfield, Vt: Ashgate Publishing, 2003), pp. 1-34.

Munro, John, 'Wage-Stickiness, Monetary Changes, and Real Incomes in Late-Medieval England and the Low Countries, 1300 - 1500: Did Money Matter?’ Research in Economic History, 21 (2003), pp. 185-297.

Munro, John, 'Gresham's Law', in Joel Mokyr (ed.), The Oxford Encyclopedia of Economic History, 5 vols. (Oxford and New York: Oxford University Press, 2003), vol. 2, pp. 480-1.

Munro, John, 'Money, Prices, Wages, and "Profit Inflation” in Spain, the Southern Netherlands, and England during the Price Revolution era, ca. 1520 - ca. 1650’, História e Economia: Revista Interdisciplinar, 4:1 (2008), pp. 13-71.

Munro, John, 'The Coinages and Monetary Policies of Henry VIII (r. 1509-47)', in C. Fantazzi (translator) and J. Estes (ed.), The Collected Works of Erasmus: The Correspondence of Erasmus, Vol. 14: Letters 1926 to 2081, A.D. 1528 (Toronto: University of Toronto Press, 2011), pp. 423-76.

Munro, John, ‘Coinage Debasements in Burgundian Flanders, 1384-1482: Monetary or Fiscal Policies’, in David Nicholas, Bernard S. Bachrach, and James M. Murray, eds., Comparative Perspectives on History and Historians: Essays in Memory of Bryce Lyon (1920 - 2007), Medieval Institute Publications, Western Michigan University (Kalamazoo, MI: The Medieval Institute, 2012), pp. 314-60.

Patterson, C. C. , 'Silver Stocks and Losses in Ancient and Medieval Times', Economic History Review, 2nd ser. 25:2 (May 1972), pp. 205-35.

Phelps Brown, E. Henry; and Sheila V. Hopkins, 'Seven Centuries of the Prices of Consumables Compared with Builders’ Wage-Rates', Economica, New Series, 23: no. 92 (Nov. 1956), pp. 296-314: reprinted in E.H. Phelps Brown and S. V. Hopkins, A Perspective of Wages and Prices (London: Methuen, 1981), pp. 13-59.

Rolnick, Arthur; François Velde, and Warren E. Weber, 'The Debasement Puzzle: An Essay on Medieval Monetary History’, Journal of Economic History, 56:4 (December 1996), pp. 789-808.

Sargent, Thomas; and François Velde, The Big Problem of Small Change (Princeton and Oxford: Princeton University Press, 2002).

Spooner, Frank, The International Economy and Monetary Movements in France, 1493-1725 (Paris, 1956; Cambridge, MA: Harvard University Press, 1972, for the English edn). 
Spufford, Peter, Monetary Problems and Policies in the Burgundian Netherlands, 1433-1496 (Leiden: Brill, 1970).

Spufford, Peter, Money and Its Use in Medieval Europe (Cambridge: Cambridge University Press, 1988).

Spufford, Peter, 'Debasement of the Coinage, its Effects on Exchange Rates and the Economy in England in the 1540s, and in the Burgundian-Habsburg Netherlands in the 1480s', in John Munro, ed., Money in the PreIndustrial World: Bullion, Debasements and Coin Substitutes (London: Pickering \& Chatto Ltd., 2012), pp. 6385.

Van Gelder, Herman Arend Enno; and Marcel Hoc, Les monnaies des Pays-Bas bourguignons et espagnols, 1434-1713: Répertoire générale (Amsterdam, J. Schulman, 1960).

Van der Wee, Herman, The Growth of the Antwerp Market and the European Economy (fourteenth-sixteenth centuries), 3 vols. (The Hague: Martinus Nijhoff, 1963).

Velde, François; Warren Weber, and Randall Wright, 'A Model of Commodity Money, with Applications to Gresham’s Law and the Debasement Puzzle’, Review of Economic Dynamics, 2:1 (1999), pp. 291-333. 